\title{
大人の動作と幼児による語の意味の推測との関係
}

\author{
— 4 歳児と 6 歳児における発達的検討——
}

小 林 春 美 $^{1}$

\begin{abstract}
本研究では, 大人が適切な動作を提示した場合, 4 歳児と 6 歳児はことばの意味の推測において, 個 別性のある事物（個物， solid objects）の，動作に関連する属性に注目できるかを検討した。実験では，実 験者は 36 人の 4 歳児と 33 人の 6 歳児 (いずれも日本児) に対し，見慣れない標準刺激の個物を無意味ラベル とともに提示した。実験者は標準刺激の形に注目する動作(例 転がす)または材質に注目する動作(例 握 り潰す)を行った。子どもたちはその後同じラベルで呼べるのは，標準刺激と形が同じ事物または材質が 同じ事物のうちどちらかを選択するよう求められ，その理由ゔけも求められた。結果は，無意味ラベル の意味の推測において，いずれの年歯群の子どもたちも動作の情報を使ったことが示された。6 歳児は 4 歳児よりも，動作に関連する事物の属性により巧みに注目していた。語柔獲得における大人の入力と 動作の役割の重要性が議論された。
\end{abstract}

キーワード：ことばの意味の獲得，意味の推測，個別性のある事物，動作，大人による入力。

ある語と事物の間の関係性は無限に存在しうる (Quine, 1960)。一方, 語彙獲得は, 語彙の爆発的増加が 始まる1歳半頃より急速に進むことが研究者間で共通 の認識となっている (Carey, 1978; Nelson, 1988)。ある語 と事物の関係が無限に存在しうるなら, 事物名称を獲 得する際に子どもがもしその関係性を 1 つ 1 つ仮説検 証していくと仮定すると, 語彙獲得には膨大な時間が かかるはずである。これでは語彙の急速な増加を説明 できなくなる。そこで語彙獲得を単純な仮説検証過程 と考えるのは困難との認識から, 子どもは何らかの原 理や制約を使っているとの考えが提出されている

(Carey, 1988 ; Markman, 1989)。

Soja, Carey \& Spelke (1991) は，子どもは事物名称 を学ぶ際に「存在論的カテゴリー (ontological categories)」を使っている，と主張した。存在論的カテゴ リーとは,「コップ」,「指輪」などのような個別性のあ る個物 (solid objects) と，「ミルク」「砂」のような個別 性のない物質 (nonsolid substances) を区別をするような カテゴリーを指す。 2 歳児は, 個物がラベルづけされ ると，「材質」は異なっていても同じ個物と見なせる物 (同じ形の事物) を同じラベルで呼べると判断した。一 方, 個別性のない物質がラベルづけされると, 物質全 体の「形」は無視して，同じ物質と見なせる物 (同じ材 質の物)を同じラベルで呼べると判断した。ここで, 形 とは，空間や他の事物との境界線によって囲まれた事

1 共立女子大学
物の部分を指す。材質とは，事物の物理的成り立ちを 指す (Soja, Carey \& Spelke, 1991 を参考とした定義)。Soja らは, 統語的知識を未獲得でも幼児は事物の存在論的 カテゴリーを使って語の意味の推測を行うことができ ると結論した。この結果は，ほほ同一の実験を日米の 子ども・大人を被験者にして行った Imai \& Gentner （1997）により，可算名詞・不可算名詞の区別がない日 本語を獲得している 2 歳児, 2 歳半児, および 4 歳児 においても確かめられている。一方統語的知識の重要 性を主張したのが Landau, Smith \& Jones (1988) で ある。英語では事物の名称には可算名詞 (count nouns), 物質の名称には不可算名詞 (mass nouns) を使う, とい う区別があるために，こうした文法的な情報を子ども は使っており，(英語圈の)子どもは，ある事物が可算名 詞を使って命名されると，その名詞は同じ形を持った ものを指すと解釈する，という「形バイアス (shape bias)」の説を提出した。Landau らによると，2歳，3 歳, 大人, と年齢が上がり統語知識が増すにつれ,「形 バイアス」は強まっていったという。

統語的知識の獲得以前にある存在論的カテゴリーを 強調するSoja らの説にしても，可算名詞という統語 的知識を強調する Landau らの説においても,「鉄」, 「プラスチック」,「ガラス」, というような個物を作り あげている固い材質については, 新奇な語の意味の帰 納を行うことは抑制されることになる。では子どもは そうした個別性のある事物の材質 (solid substances, 個別 性のある物質) について語意味の帰納を行うのは不可能 
なのだろうか。Soja（1987）は，個別性のある物質につ いては語意味の帰納は抑制されるのであり, 証拠とし て Brown (1973) で検討されたデー夕を引き，幼い子ど もでは「鉄」「プラスチック」のような固い材質を示す 語の獲得が遅れることをあげている。Dickinson(1988) はさらに, 3 歳児では新奇な個別性のある物質の名称 を学ぶのは困難であったとの報告をしている。

しかし, Prasada (1993) は, もし実験者が“made of sponge”というように“made of”という表現を使えば, 2 歳児でも個別性のある物質に基づいて事物を選択す ることができたと報告している。さらに Prasada はも う1つの実験において, クッキーモンスターがスポン ジ製の事物を握りつぶして変形させる (squeeze) ところ を子どもに見せ,「クッキーモンスターにこんなふうに 握りつぶせる (squeeze) ものをわたして」と指示したと ころ, 3 歳半児では正しく選ぶことができた。Prasada は, 2 歳半から 3 歳半にかけて, 物体の材質に関する 知識が進むと結論している。彼の研究は, 幼い子ども であっても, “made of”という言語的情報が与えられ たり, あるいは材質に関し人の動作を通して情報が与 えられたりすれば, 個別性のある物質に注目できるこ とを示した点で興味深い。

しかしながら子どもは大人の示す事物への動作の情 報を使って新奇な語と個別性のある物質を結びつけら れるかについては, Gathercole, Cramer, Somerville \& op de Haar (1995) により否定的な見解が出されて いる。Gathercole らによれば, 3 歳から 4 歳の子ども でも, 個別性のある物質とその機能との関係は明示的 になっていないという。しかし, 彼女らの実験方法に は疑問がある。彼女らが選択した個別性のある物質の 機能のうちいくつかは, 幼い子どもにとって難しすぎ た可能性がある。例えば標準刺激の 1 つは筒形の紙ヤ スリであり，材質選択として，平らな紙ヤスリが，形 選択として金属製の筒が示された。標準刺激を使った 材質機能は，「木片をこすって滑らかにする機能」(材質 に基づく動作)であった。形機能は，「(望遠鏡のように）見 る機能」であった。結果は, 子どもは材質機能を示さ れても，材質を選択するという明確な傾向は見られな かった。しかし, 紙ヤスリで滑らかにする動作と紙ヤ スリの材質の関係を, 子どもがどの程度理解できてい たかは疑問である。直感的に把握しやすい材質機能を 選択して実験を行えば，あるいは幼い子どもであって も，材質の機能と動作を関係づけられる可能性を残し ていると言えよう。

Kobayashi (1997) は語の意味の推測について, 大人
による事物への動作の重要性を示唆した。日常生活で は人間は多くの事物に取り巻かれているが，その多く は人工的であり, 人間の何らかの動作を可能とするよ うに作られている。加えて, 子どもにとって身近な事 物であればあるほど, きわめてしばしば大人の動作と ともに子どもに提示されていると思われる。とすれば, 大人がどのような動作を事物に対して行うかについて の情報を, 語の意味の推測をするにあたって子どもが 使っている可能性は充分考えられる。事実, 子どもは 大人が事物に対して行う動作を確かに観察していると いう証拠が提出されている (Banigan \& Mervis 1988 ; Ross, Nelson, Wetstone \& Tanouye, 1986)。最近では Tomasello \& Akhtar (1995) により, 子どもがある語 を動作についての語と考えるか, それとも事物につい ての語と考えるかは, 大人がどのような行動をとった かに依存していたとの報告がされている。

Kobayashi (1997) は, 大人が事物に対して異なる動 作をした場合, その動作の情報を子どもが語の意味の 推測に使えることを, 日本人の 2 歳児を被験者として 実験により示した。さらに従来の研究では難しいとさ れてきた個別性のある物質への注目について, Gathercole et al. (1995) よりさらに幼い 2 歳児であっても, 大人による適切な動作の情報があれば子どもは充分行 えることを示した。加えて, 無動作条件では形・材質 のいずれにも偏りがなかったことから, Landauらの 提出した「形バイアス」は, 少なくとも可算名詞が存 在しない日本語を獲得している日本人の 2 歳児におい ては見られないことを示唆した。しかしながら， Kobayashi の研究はいくつかの課題ももたらした。第 1 は動作の情報の利用の発達的検討である。動作の情 報への敏感性は年粭とともに果たして高まっていくの か, それとも制約, バイアス等と呼ばれる, 語彙獲得 において提案されている原理に道を譲っていくのか, あるいは何らかの交互作用を伴い共存していくのであ ろうか。第 2 は事物の固さについての情報を子どもは 語の意味の推測に使うかどうかという問題である。 Kobayashi は, 人間の動作が事物に対し起きた場合, 事物の変形が起こるかどうかにより, 子どもが事物の 形に注目する度合いが変わる可能性についても検討し た。1つの実験では事物の固さ (object rigidity) は子ど もの事物選択に有意な差をもたらし, 固い物(例えば鉄) では, 柔らかい物 (例えばスポンジ)よりも子どもは形に 注目した選択をしやすいことが示された。これは, Landau らが提出した「形バイアス」は, Landau らが 示唆するように, どの様な固さの事物に対しても子ど 
もが同じ強さで持つ原理なのではなく, 事物の固さに よって強さの異なる原理である可能性を示している。 しかし Kobayashi が, 全体の実験デザインを変更して 行ったもう 1 つの実験（要因の追加および動作の要因を被験 者内要因に変更)では, 有意差は見られなかった。事物の 固さと形への依存の関係について,さらに検討するこ とが必要である。第 3 は, 果たして子どもは事物選択 をした場合, 本当に実験者が示した動作の情報に基づ いて選択をしていたかどうかという問題である。2 歳 児では事物選択を行うことはできても，その理由を言 語的に説明することは不可能であった。そこで理由を 言語で説明できる年齢の子どもに尋ねることにより， 子どもによる情報の利用と語意の推測についてより詳 細に調べることが必要である。

本研究では動作の情報の利用についての Kobayashi の実験 1 とほほ同一の実験を保育園の年少児 $(4$ 歳 児) と年長児 (6 歳児) に対して行うとともに, さらに選 択の理由を尋ねるという手続きを実験に加えることに より，以上の 3 点を検討することを目的とした。

\section{方 法}

被験児 横浜市内の保育園の年少児 36 人 (レンジ 47 -59 力月, 平均月秢 53.1 力月, 男女比ほほ $1: 1)$, 年長児 33 人( ンジ71-83 カ月, 平均月齢 77.8 力月, 男女比ほほ $1: 1)$ 。子ども たちは各年齢ごとにランダムに形動作条件, 材質動作 条件, 無動作条件 (統制) の 3 群に割り当てられた。男 女比はいずれの群もほほ 1：1であった。

材料 Kobayashi (1997) の用いた実験材料を若干改 善したものを使った。材料は 1 セットが 3 個の事物か らなり，うち 1 個の事物を標準刺激とし，命名場面で 使った。残りの 2 個をテスト刺激とし, 命名場面の効 果を調べるためにテスト場面で使った。それぞれの事 物はすべて, 色, 形, 材質がはっきりした特徵を持つ 物を選んだ。 2 個のテスト刺激は標準刺激に対し, 形 または材質の一方の属性を同一とし，もう一方の属性 は異なっているように作成した。一例として, 黄色い ガラス製で卵形のペーパーウェイトを標準刺激とし, テスト刺激として，ガラス製でピラミッド形の物(同じ 材質で異なる形) と，木製で卵形の物 (異なる材質で同じ形) の 2 個を用いた。同様なセットを，鉄のような固い物 (rigid objects)を標準刺激とする 4 セット，スポンジの ような柔らかい物 (flexible objects) を標準刺激とする 4 セットの計 8 セットを用意した。TABLE 1 に, 固い物 を標準刺激とする 4 セットすべての形・材質と, それ ぞれのセットの標準刺激に対する形動作・材質動作を,
TABLE 2 に，柔らかい物を標準刺激とする 4 セットす べてについて同様に示す。固い物の基準は，人間の通 常の力を加えても変形しない物であり, ガラス, 真鍮, 鉄，プラスチックを標準刺激の材質として用いた。柔 らかい物の基準は, 人間の通常の力を加えると変形す る物であり, スポンジ, ゴム, 網, 海綿を標準刺激の 材質として用いた。形動作とは, 空間や他の事物との 境界線によって囲まれた事物の部分 (形) と人間の身体

TABLE 1 Shape and Material of Rigid Object Sets and Actions

\begin{tabular}{|c|c|c|c|}
\hline Standard & Test item 1 & Test item 2 & $\begin{array}{l}\text { Actions (S: Shape action, } \\
M: \text { Material action) }\end{array}$ \\
\hline egg-shape, glass & egg-shape, wood & pyramid-shape, glass & $\begin{array}{l}\text { S : roll it } \\
M: \text { look through it }\end{array}$ \\
\hline $\begin{array}{l}\text { rectangle-shape with a } \\
\text { hole, brass }\end{array}$ & $\begin{array}{l}\text { rectangle-shape with a } \\
\text { hole, plastic }\end{array}$ & mountain-shape, brass & $\begin{array}{l}S \text { : place one's finger in } \\
\text { its hole and swing it } \\
M: \text { look at oneself in it }\end{array}$ \\
\hline screw joint ${ }^{*} 1$, steel & screw joint, plastic & flat fitting* 2 , steel & $\begin{array}{l}S: \text { screw it } \\
M \text { : bring a magnet close } \\
\text { to it }\end{array}$ \\
\hline $\begin{array}{l}\text { odd disk* } 3 \text {, synthetic } \\
\text { resin } 4\end{array}$ & odd disk, wood & $\begin{array}{l}\text { ameba-shape, synthetic } \\
\text { resin }\end{array}$ & $\begin{array}{l}S: \text { spin it } 5 \\
M: \text { look into it }\end{array}$ \\
\hline $\begin{array}{l}\text { 注:"1 祙により鎖をつ } \\
\text { "2 平らな止め金具の } \\
\text { "3 欠けたところのあ }\end{array}$ & $\begin{array}{l}\text { なぐ部品の一種 } \\
\text { 一種 } \\
\text { る円盤 }\end{array}$ & $\begin{array}{l}\text { *4 プラスチックの一種 } \\
\text { "5コマのように回す }\end{array}$ & \\
\hline
\end{tabular}

TABLE 2 Shape and Material of Flexible Object Sets and Actions

\begin{tabular}{|c|c|c|c|}
\hline Standard & Test item 1 & Test item 2 & $\begin{array}{l}\text { Actions (S: Shape action, } \\
\text { M : Material action) }\end{array}$ \\
\hline hat-shape, sponge & hat-shape, hard rubber & drum-shape, sponge & $\begin{array}{l}\text { S: put one's finger in its } \\
\text { hollow } \\
\text { H: squeeze it }\end{array}$ \\
\hline circle, rubber & $\begin{array}{l}\text { circle, copper covered } \\
\text { by cotton, }\end{array}$ & baton-shape, rubber & $\begin{array}{l}\mathrm{S} \text { : hang it around one's } \\
\text { wrist } \\
\mathrm{M} \text { : stretch it }\end{array}$ \\
\hline $\begin{array}{l}\text { flower-shape, } \\
\text { mosquito net }\end{array}$ & flower-shape, plastic & $\begin{array}{l}\text { dumpling-shape }{ }^{*} 1 \text {, } \\
\text { mosquito net }\end{array}$ & $\begin{array}{l}\text { S: place it on one's } \\
\text { chest*2 }^{*} \\
M: \text { push it }\end{array}$ \\
\hline $\begin{array}{l}\text { cone-shape, natural } \\
\text { sponge }^{*} 3\end{array}$ & $\begin{array}{l}\text { cone-shape, synthetic } \\
\text { resin*4 }\end{array}$ & $\begin{array}{l}\text { round-shape with some } \\
\text { hollows, natural } \\
\text { sponge }\end{array}$ & $\begin{array}{l}\mathrm{S}: \text { place it in a small } \\
\text { paper house } \\
\mathrm{M} \text { : bend it }\end{array}$ \\
\hline
\end{tabular}

\begin{tabular}{|c|c|}
\hline 注："1 餃子の形 & *3 海綿 \\
\hline 吃胸につける & 4プラスチックの一種 \\
\hline
\end{tabular}


との関係の中で成り立つ人間の動作を指す。材質動作 とは，事物の物理的成り立ち(材質) と人間の身体との 関係の中で成り立つ人間の動作を指す。ここで人間の 身体を介在させているのは，人間が知覚的・直感的に 捉えられないような形 (例えば地球のようにあまりにも大き い球の形) や，材質（例光ば人間の知覚では捉えられないよう な物質の表面の微細な状態) は, 人間の動作が適用され得な いため, 考察の対象から外すことを示している。色は, その属性だけに基づいて選択が行われることを防ぐた めに，1セットの事物間でできるだけ同一とするよう に努めた。具体的には木やゴムに絵の具を塗るなどし た。しかし，材質そのものの性質のために，材質が異 なるテスト刺激の場合，標準刺激の色合いと完全に同 じにすることは当然ながら不可能である。例えば，黄 色いガラスと, 黄色く塗った木では同じ「黄色」でも 色合いの性質は異なるのであり，「色」を統一したのち も材質の特徵は維持されていた。ラベルは, 梅本・森 川・伊吹 (1955) による無連想価が50以上の清音 2 字に よる無意味音節及び梅本 (1951) による連想価が50以下 の濁音・半濁音を含む 2 字による無意味音節から, Kobayashi (1997) が使用した音節と同一または近い音 節を選んだ。使用した音節は, ム夕, パプ,メヌ, ラ へ,ワグ，ルモ，ピド，ホミであった。

手続き 実験は保育園の中の静かな一室で個別に 行った。実験者は「これはム夕 (無意味音節) です」と標 準刺激を子どもに見せ，「ム夕でこんなことができま す」と言いながら，標準刺激を使ってある動作を行い (約 3 秒),「○○ちゃんも同じようにやってごらん」と 促し, 自由に約 5 秒間標準刺激に触れさせる。次に 2 つのテスト刺激を見せ，「どっちがム夕かな」と尋ね た。子どもがいずれかのテスト刺激を選ぶなどの回答 をしたら，「どうしてこれがム夕だと思ったの？」と事 物選択の理由を尋ねた。実験者が提示した動作は, 形 動作条件では，「転がす」というような事物の形に注目 した動作，材質動作条件では，「透かしてみる」という ような事物の材質に注目した動作，さらに無動作(統制 条件)の 3 種類であった。無動作条件では, 実験者は「こ れはム夕です」と言いながら静かにテーブルの上に標 準刺激を置き，「よく見てね」と言いながら 3 秒ほど経 過したあとで，「自由に遊んでいいですよ」と教示し， 約 5 秒間子どもに自由に触れさせた。その後の事物選 択や，その理由づけについては他の条件と同一であっ た。 8 セッの刺激の提示順序は各実験群の被験児間 でカウンターバランスさせた。

なお, 本実験では, Kobayashi (1997) の方法とは,
材料，手続きに若干の違いがある。主たる違いは次の ようである。材料については, Kobayashi では固い物 のセットの一部に「発泡スチロール」を使っていた。 これは, Kobayashi の被験児であった 2 歳児にとって は変形可能なものではなかったが，予備実験を行った ところ，4，6歳児の一部には爪で発泡スチロール製 の卵形の事物の表面を削り取る子どもがいた。このこ とから, 発泡スチロールは 4 歳以上児にとっては何ら かの変形が可能なものであり,「固い物」に完全に属す るとは言えなくなったので，「木」に変更した。次に， 無意味音節は, Kobayashi は日本人の大人数名に音節 を評定してもらう方法で決定したが，本実験では梅本 らの無意味価表などを用いて決定した。手続きについ ては，2 歳児では言語での指示は「ム夕を見てね」で あったが，本実験ではこうした場合に日本語でより自 然な指示と思われる「これはム夕です」とした。次に, 2 歳児では自由に標準刺激に触れる時間を15秒とした が，本実験では 5 秒とした。さらに，2 歳児では， 2 つのテスト刺激の両方に自由に触れさせたのち選択を

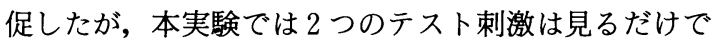
あった。この手続きの変更は, 予備実験の結果, 4 歳 以上児では短時間で事物検索が終了するため, 時間が 長いとかえって集中しにくくなること，ほとんどの子 どもが 2 つのテスト刺激を見ただけですぐ事物選択を 行うことが観察されたため決定した。

\section{結 果}

\section{事物選択の結果}

Kobayashi (1997) と同様の算出方法に基づいて子ど もの回答を点数化した。すなわち, 各試行で形に基づ く選択をした場合に 1 点, 材質に基づく選択をした場 合に 0 点とし， 1 人につき 8 回の試行における得点の 合計を算出した。まれに両方の刺激とも標準刺激と何 らかのやり方で同じ（「こっちは形が同じ,こっちはふわふわ で同じ」など）という回答があった。この場合，形・材質 のいずれにも偏りのない選択がされたと考えて 1 試行 につき0.5点とした。

動作条件 (3) ×年齢 (2) ×事物の固さ (2) の 3 要因分 散分析を行った。その結果, 動作条件の主効果が $0.1 \%$ 水準で有意だった $(F(2,62)=17.334)$ 。FIGURE 1 に各年粭 群の子どもたちがそれぞれの動作条件において形に基 づく選択をした率 (\%)の平均を示す。対間比較 (Tukey 法)により, 材質動作条件は, 形動作条件と無動作条件 のいずれとも $1 \%$ 水準で有意差があった。さらに動作 条件の年齢要因における単純主効果を検定した結果, 


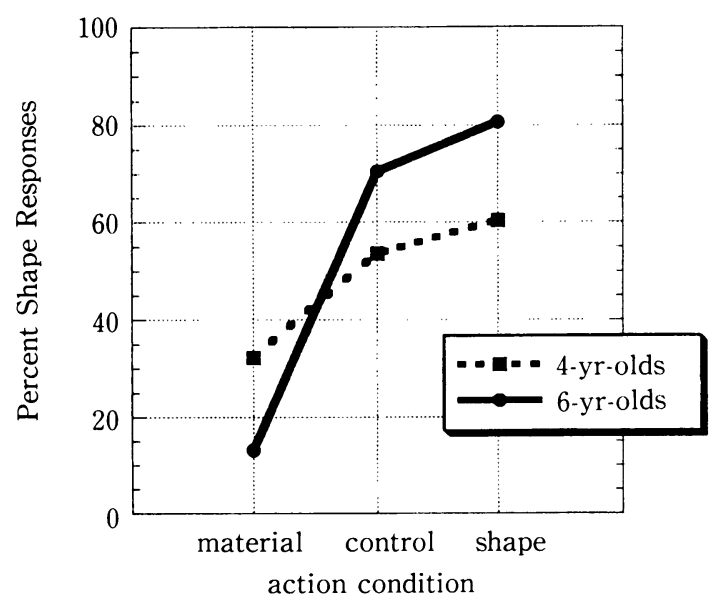

FIGURE 1 Percent Shape Responses by 4- and 6 year-olds

いずれの年齢とも $1 \%$ 水準で有意だった（年少児 $F$ $(2,63)=11.457$, 年長児 $F(2,63)=70.602)$ 。このことから, 動作 条件の違いは確かに幼児の事物選択に影響したこと, それは年少，年長のいずれの年齢でも起こったことが 示された。分散分析のその他の結果では, 動作条件 $\times$ 年齢の交互作用のみが $5 \%$ 水準で有意, $(F(2,63)=3.177)$ あとはすべて有意ではなかった。対間比較 (Tukey 法) により，この交互作用は，材質動作条件で年少児 8 試 行中平均值 2.58) が年長児 (平均值 1.05) より有意に多く形 に基づく選択を行っていた一方, 形動作条件では年長 児 (平均值 6.46) が年少児 (平均值 4.83) より有意に多く形 に基づく選択をしていたために起こっていたことがわ かった ( $p<.05)$ 。このことから，年長児は年少児よりも 材質動作条件ではより材質に注目した選択をする一方, 形動作条件ではより形に注目した選択をしており，動 作情報により敏感に反応していたことがわかった。さ らに無動作条件では, 年長児 (平均值 5.64) は年少児 (平 均值 4.29）より多く形に基づく選択をする傾向が見られ た( $(p<.1)$ 。もし子どもが形と材質のどちらにも偏りのな い選択をするとすれば，形を選ぶ確率は $50 \%$ と考えら れる。無動作条件での年少児の形に基づく選択をチャ ンス・レベルと比較したところ，有意差はなかった。 年長児では，チャンス・レベルよりも多く形に基づく 選択をしていた $(p<.05)$ 。このことから, 動作があると きは年長児はその情報を巧みに取り込んで選択をする 一方, 動作がないときは年長児は形に基づく選択をす る傾向があると言えよう。なお, 事物の固さの主効果 は有意ではなく, 有意な傾向にとどまっていた（F
$(1,63)=2.948, p<.09)$ 。従って事物の固さの効果, すなわち 固い物質でできた事物では，柔らかい物質でできた事 物に比べ，子どもはより事物の形に注目するのかどう かについて, 明確な結論は得られなかった。

事物選択のしかたの年齢群ごとの特徵を調べるため に, 各条件の各年齢群ごとに形に基づく選択(S:Shape) を材質に基づく選択 (M : Material)より多く行っていた $(\mathrm{S}>\mathrm{M})$ 子どもの数, 同じ頻度で行っていた $(\mathrm{S}=\mathrm{M})$ 子 どもの数，材質に基づく選択を形に基づく選択よりも 多く行っていた $(\mathrm{S}<\mathrm{M})$ 子どもの数を調べた。 4 歳児は 形動作条件で, $\mathrm{S}\rangle \mathrm{M}$ は 8 人, $\mathrm{S}\langle\mathrm{M}$ は 4 人, $\mathrm{S}=\mathrm{M}$ は 0 人, 材質動作条件で $\mathrm{S}>\mathrm{M}$ は 4 人, $\mathrm{S}\langle\mathrm{M}$ は 8 人, $\mathrm{S}=\mathrm{M}$ は 0 人とばらつきがあったのに対し，6歳児では形動 作条件で全員が形に傾く選択をし，材質動作条件では 1 人を除いて全員が材質に傾く選択をしていた。符号 検定により，6歳児ではこの 2 条件で有意に動作の情 報に基づく選択が行われていたことが確かめられた( 〈.01)。無動作条件ではいずれの年齢群とも, 符号検定に おいて有意な偏りは見られなかった。

\section{事物選択の理由づけの結果}

事物選択の子どもによる理由づけを動作条件ごとに 「形に基づく理由」「材質に基づく理由」「その他」「無 回答」の 4 カテゴリーに分類した。分類の基準と例を TABLE 3 に示す。「同じ色だから」というような色に基 づく理由づけはすべて「材質に基づく理由」とした。 その理由は次のようである。色は 1 セット内では統一 してあったものの, ガラスの黄色と木に絵の具を塗っ た黄色では色の性質が全く異なっている。子どもが同 じ材質・異なる形のテスト刺激について，「(標準刺激と) 同じ色だから」という理由づけをした場合は，これは 色の性質, または色合いについて述べている考えら れる。この色の性質, または色合いは材質の違いによっ

TABLE 3 Categories of Reasons and Examples Which Children Provided

\begin{tabular}{|c|c|c|c|}
\hline $\begin{array}{l}\text { 形に基ゔ理由（形に基 } \\
\text { うく動作含む） }\end{array}$ & $\begin{array}{l}\text { 材質に基うく理由（材質 } \\
\text { に基うく動作含む) }\end{array}$ & $\begin{array}{l}\text { その他 (形・材質のいず } \\
\text { れにも分類不能の理由) }\end{array}$ & 無回答([知らない含む) \\
\hline (冽) & (副) & (侧) & (無回答) \\
\hline 同じ形だから & 黄色だ加ら & こっちと違うから & 知らない \\
\hline こっちちようちょ形 & 光ってろから & だって同じたから & \\
\hline 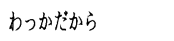 & 的的力 & 簡単だ加ら & \\
\hline 丸穴あいてろ加 & ぱつはつがある & ム夗似てるから & \\
\hline 回ろ加ら & こっち固くないから違う & うちの圻母さ持ってる & \\
\hline 䡜すもののだから & $\begin{array}{l}\text { こうできるから(引っ } \\
\text { 張って伸侍す) }\end{array}$ & 加号 & \\
\hline
\end{tabular}


てもたらされたので，色に基づく理由づけはすべて材 質に基づく理由づけとした。

子どもによる理由づけについて, 各年齢群の各動作 条件ごとに各理由カテゴリーにどのように分類された かについて, 百分率により TABLE 4 と 5 に示す。 $\chi^{2}$ 検 定したところ，いずれの年齢においても動作条件の違 いにより,理由の分布に $0.1 \%$ 水準で有意な差があるこ とが示された(年少児 $\chi^{2}{ }_{(6)}=61.17$, 年長児 $\left.\chi_{\left({ }_{(6)}^{2}\right.}=82.22\right)$ 。年少 児においても，年長児においても，動作条件が異なる と, 事物選択の理由づけのしかたが異なっていた。形 動作条件では「形が同じ」「丸いから」というょうな形 に基づく理由づけが多く，一方材質動作条件では「同 じ色だから」「ふわふわしてるから」というょうな材質 に基づく理由づけが多い。少数だったが，「転がせるか ら」(形動作条件)，「くしゃってできる(手で握り締めて淇 すこと) から」(材質動作条件）というように，属性のみな らず，その属性を使った動作を理由としてあげていた 子どももいた。

表から, 年少児の場合は形動作条件では形に関する 理由づけとその他が多く，無動作条件ではその他と無 回答が多いこと，材質動作条件では材質に基づく理由 づけが多いことが伺える。年長児では形動作条件では 圧倒的に形に関する理由づけが多く, 無動作 (統制) 条 件でも形に関する理由づけが多い。一方，材質動作条 件では材質に関する理由が多くなっていた。年長児で は年少児と異なり，全般的にその他と無回答は少な かった。年齢によって理由づけのしかたが条件ごとに 異なるのかどうかをさらに条件ごとに $\chi^{2}$ 検定したと ころ,いずれの条件においても，0.1\%水準で年齢群ご

TABLE 4 Reasons Which 4-year-olds Provided (\%)

\begin{tabular}{c|c|c|c|c}
\hline $\begin{array}{c}\text { Reason } \\
\text { Condition }\end{array}$ & $\begin{array}{c}\text { Reason based } \\
\text { on shape }\end{array}$ & $\begin{array}{c}\text { Reason based } \\
\text { on material }\end{array}$ & Other & No response \\
\hline Shape & 30.7 & 16.1 & 34.4 & 18.8 \\
\hline Control & 9.9 & 6.3 & 35.9 & 47.9 \\
\hline Material & 15.6 & 40.6 & 18.8 & 25.0 \\
\hline
\end{tabular}

TABle 5 Reasons Which 6-year-olds Provided (\%)

\begin{tabular}{c|c|c|c|c}
\hline $\begin{array}{r}\text { Reason } \\
\text { Condition }\end{array}$ & $\begin{array}{c}\text { Reason based } \\
\text { on shape }\end{array}$ & $\begin{array}{c}\text { Reason based } \\
\text { on material }\end{array}$ & Other & No response \\
\hline Shape & 72.7 & 19.3 & 2.3 & 5.7 \\
\hline Control & 51.1 & 25.0 & 14.8 & 9.1 \\
\hline Material & 13.6 & 69.3 & 4.6 & 12.5 \\
\hline
\end{tabular}

とに理由づけのパターンに違いが見られた（形動作条件 $\chi^{2}{ }_{(3)}=47.32$, 無動作(統制)条件 $\chi^{2}{ }_{(3)}=68.32$, 材質動作条件 $x^{2}{ }_{(3)}=$ 18.78)。この結果と表から, 年長児は形動作が示される と年少児よりも多く形に基づく理由づけが行えること， 無動作条件では年長児は年少児に比べその他や無回答 が少なく，形や材質，とりわけ形に関する理由づけを 多く行っていたと言える。一方, 材質動作条件では年 長児は年少児よりもさらに多く材質に基づく理由づけ を行っていた。理由づけの分析の結果は事物選択の結 果とよく一致しており，年長児では動作の情報を確実 に使い, しかも理由づけも動作の情報が関わった事物 の特定の属性に注目し，その属性についてかなりょく 言語化して答えられることがわかった。年少児は年長 児より全般的にその他や無回答が多く的確な理由づけ を行えない子どももいたものの, 形動作では形に，材 質動作では材質に基づく理由づけをある程度よく行う ことができ, 動作の情報を取り込んで事物選択を行っ ていることが, 理由づけの分析からも確かめられたと 言える。

\section{討 論}

本研究の目的は, 保育園の年少児 (4 歳) と年長児 $(6$ 歳)が, 大人が事物に対して行う動作を，ことばの意味 の推測の際に情報として利用するかどうかを調べるこ とであった。その結果, 子どもたちは確かに大人の動 作を情報として利用していたこと，4歳から 6 歳の間 に動作情報への敏感性が高まり，理由づけの分析もそ の知見を支持したことが示された。

\section{動作情報の利用}

Kobayashi (1997) が 2 歳児において示した大人によ る事物への動作の情報の取り込みは，4歳児，6歳児 でも行われていることが確かめられた。本研究の 4 歳 児, 6 歳児は, Kobayashi $の 2$ 歳児よりもやや難度が 高い課題を与えられていたが，標準刺激提示時に同時 に与えられた無意味シラブルの意味の推測のしかたは 動作の性質によって異なっており，子どもは「同じょ うな動作ができる事物」を選択した。加えて本実験で は, 同一の手続きで 4 歳と 6 歳の 2 つの年齢群の子ど もたちを比較することにより, 発達的変化を明らかに した。 4 歳児, 6 歳児のいずれも, 動作の性質に応じ て事物選択を行っていたが, 形動作条件において 6 歳 児は 4 歳児よりもより形に傾く選択をした一方，材質 動作条件では 6 歳児は 4 歳児よりもより材質に傾く選 択をしていた。年長児は動作の情報にさらに敏感であ り，より巧みに動作情報を取り込んでいた。 


\section{形バイアスと動作の関係}

本実験では，動作情報の取り込みという環境からの 入力への敏感性に加え, 子どもの持つ原理と動作情報 の取り込みが相互作用を起こすらしいことも示唆した。 動作無しで単に標準刺激を提示しただけ（統制条件）の 場合, 年少児は Kobayashi の 2 歳児と同様に, チャン ス・レベルよりも多く形に傾く選択をすることは見出 せなかったが，年長児ではチャンス・レベルよりも多 く同じ形のテスト刺激を選択していた。このことは, 年長児では動作が示されず単に事物が提示され他に手 がかりが何もないときは，ことばの意味の推測をする 際「形」を重視することを示している。Landau らは形 バイアスについて「(英語圈の) 子どもが count noun を 聞いたとき」と限定しているが，これは日本語のよう な, 可算名詞・不可算名詞の区別のない言語では, 言 語の統語規則とは無関係に発現する可能性があると言 える。子どもは何も手がかりが与えられないときは, とりあえず形に注目してことばの意味の推測を行うが, それは英語児よりも遅く，4歳以降明らかとなるよう だ。使用言語によって同年齢においても形への注目度 が異なることは, 最近の Imai \& Gentner（1997）の日 本児・米国児の比較研究結果とも一致している。Imai \& Gentner は, 単純な形の事物においては, 日本の 2 歳から 4 歳児は米国の同年齢児に比べ形への注目度が 明らかに低いことを見出しており，獲得言語の影響を 指摘している。

しかし, 本研究の骨子は動作情報の取り込みを示す ことにある。子どもは動作情報があればそれに基づい た選択をすることは，動作情報が形バイアスと競合す る材質動作条件において，はっきり示されたと言えよ う。形動作条件では形バイアスが促す反応と動作が促 す反応が重複し, 競合は起こらない。そこでどちらが 優先されるかは判定できない。しかし材質動作条件で は，形バイアスは同じ形の事物へ，材質動作は同じ材 質の事物へと，それぞれ異なったことばの推測を促す。 本研究では, こうした際に優先されるのは動作情報で あることをはっきり示した。年少，年長とも材質動作 条件では形よりも材質に傾く選択をし, しかもその傾 向は形バイアスが発現してきたと見られる年長児でむ しろ著しく，1 人を除いて全員が材質に偏る選択をし ていた。この結果から年長児では形バイアスの効果が 見られる一方，これはあくまで動作の情報が欠如して いた場合に限るのであり，動作情報があればそれが優 先されることが示されたと言える。形バイアスは，そ れが生得的であるか経験から習得したものであるかは
特定できないが，いずれにしても子どもの内的原理 (Landau et al., 1988) と考えられている。一方, 動作の 情報は環境から与えられる入力である。本研究は語彙 獲得において, 内的原理が環境からの入力と相互作用 すること,さらに年長児は環境からの入力を優先させ るようになることを示した。この結果は, 相互排他性 (内的原理) と文脈（環境からの入力）との相互作用を示 し，年長児では文脈が優先されるようになることを示 した針生 (1991) の知見に通じる。子どもの内的原理だ けでは，広範かつ複雑なことばの意味の獲得はかえつ て阻害される場合があることが指摘されている。内的 原理あるいは制約の克服のためには，環境からの入力 の取り込みが必要であり，本研究はこうした入力の解 明に寄与すると考えられる。

\section{事物の固さの効果}

本研究では事物の固さによる効果はかろうじて有意 傾向 ( $p<.09)$ であり, 事物の固さの効果は一応確かめら れた。つまり，人間が力を加えても容易に変形しない 物質(鉄など) で作られた事物では，子どもたちは形に 偏る選択をするが，人間が力を加えると容易に変形す る物質（スポンジなど）で作られた事物では，子どもたち は形に偏る選択をする割合は低い傾向があると解釈さ れる。有意には至らなかったので，事物の固さの効果 についてさらに検討を要する。

\section{理由づけの発達}

本研究では, 子どもたちが確かに実験者が提示した 形または材質動作の情報を取り込み，形または材質に 基づく理由づけを行っていたこと，さらに，この理由 づけは加齢に伴いより巧みにできるようになることが 示された。理由づけのしかたには年齢差が見られ，4 歳児では全般的に「その他」と「無回答」が多かった が，6歳児では「その他」と「無回答」は少なく, 形 または材質に基づく理由づけが多くなっていた。これ は，年少児では事物選択の理由づけを言語で説明する ことが困難であることを示した針生・大村・原 (1994) の研究や, 意味的基準に基づいて自分の助数詞使用に ついてシステマティックに理由づけを行えるようにな るのは 5 歳後半過ぎであったという, 内田・今井(1996) の分析とも通ずる結果である。しかし本研究では，4 歳児でも動作条件により理由づけのしかたに有意な差 が見られたことから，4歳でも形や材質に関する理由 づけについてはある程度は行えるようになっていると 言える。6 歳児では形動作条件では形に, 材質動作条 件では材質に基づく理由づけをするという傾向が圧倒 的となり，それぞれの動作条件での事物選択における 
結果とよく一致していた。理由づけの分析からも，年 齢による動作情報の取り込みの発達が裏付けられたと 言えよう。無動作 (統制) 条件での各年齢群による理由 づけのしかたにも大きな違いが見られ，4歳児では「無 回答」が回答数全体の半数近く $(47.9 \%)$ を占めており, この条件における事物選択において 4 歳児の回答が チャンス・レベルであり，いわばランダムにしか反応 しなかったことと符合する。一方，6歳児では無動作 条件で最も多い理由づけは「形に基づく理由」であり, 回答数全体のほほ半数（51.1\%）を占めていた。これは, 6 歳児が事物選択においてチャンス・レベルよりも多 く形に基づく選択をした結果に符合する。6 歳児では, 動作が示されない場合は形を重視してことばの意味の 推測を行っていたことが, 理由づけの分析からも確か められた。

\section{語彙獲得研究への示晙}

第 1 に, 子どもは語彙獲得において確かに大人から の入力の影響を受けており，その入力は動作というょ うな非言語的な入力であっても，ことばの意味の推測 のしかたを決定づけるほど強力でありうるということ である。荻野(1995), Snow, Perlmann \& Nathan(1987) は言語獲得における養育者からの入力の影響の研究を レビューし，子どもの言語と養育者の言語を相関させ るというような研究の多くは，二者の間にはっきりし た関係を見出せないでいると指摘している。本研究は, 子どもは幼いときから大人の行う事物への動作に敏感 であり，動作の情報を語意の推測にも用いることがで きることを実験により示し, 養育者の入力が影響力を 持ちうることを明確に示した。この結果は, Tomasello \& Akhtar (1995) が実験により示した，子どもは大人 が事物に対して行う動作を観察し，与えられた語が事 物についての語かそれとも動作についての語なのかの 推測を行ったという結果にも一致する。本研究は Tomasello らの研究よりさらに詳しく,「事物につい ての語であっても,さらにその事物のどの属性に注目 して語の意味の推測を行うべきか」について, やはり 子どもは動作の情報を取り込めることを示した。

第 2 に, 事物は子どもにとって「ある動作が可能な 物」として認識されており，大人が示した動作と同じ 動作が可能な物に事物名称を結びつける傾向があると いうことである。佐々木(1994)によれば, J.Gibson(1979) による「アフォーダンス」とは「動物との関係として 定義される環境の性質」である。事物は単に数々の属 性を装備しているだけの存在ではなく, 人間の様々の 操作を誘発するような「アフォーダンス」に満ちてい
るとされる。コップは液体を入れておく・透かして眺 める・武器として投げるなどいろいろのアフォーダン スを持つ。このうち液体を入れて飲むという動作をア フォードすることが私たちの文化では最重要であり, コップとはまさにそれを可能とする性質を持つ事物の カテゴリーの名称と言えるのではないだろうか。本研 究は, 大人が事物に対してどのような動作をするかに よって子どもがことばの意味の推測のしかたを変える ことを示したことにより，事物が大人の動作により， 特定の文化において特別に意味づけられた存在である ことを，子どもたちが知っている可能性を示唆したと 考える。

\section{引用文献}

Banigan, R.L., \& Mervis, C.B. 1988 Role of adult input in young children's category evolution: II. An experimental study. Journal of Child Lan guage, 15, 493-504.

Brown, R. 1973 A first language : The early stages. Cambridge, MA. : Harvard University Press.

Carey, S. 1978 The child as a word learner. In M. Halle, G. Miller, \& J. Bresnan (Eds.), Linguistic theory and psychological reality. Cam. bridge, MA : MIT Press.

Carey, S. 1988 Lexical development-the "Rockefeller years." In W. Hirst (Ed.), The making of cognitive science (Pp. 197-209). New York : Cambridge Univ. Press. 小林春美（訳）「語の 獲得」安西祐一郎・波多野誼余夫・石崎俊・溝 口文雄・大津由紀雄編 認知科学ハンドブック 共立出版

Dickinson, D.K. 1988 Learning names for materials : Factors constraining and limiting hypotheses about word meaning. Cognitive Development, 3, 15-35.

Gathercole, V.C.M., Cramer, L.J., Somerville, S.C., \& op de Haar, M.J. 1995 Ontological categories and function: Acquisition of new names. Cognitive Development, 10, 225-251.

Gibson, E.J. 1979 The ecological approach to visual perception. Boston, MA : Houghton Mifflin Company. 古崎敬・古崎愛子・辻敬一郎・ 村瀬旻（訳）生態学的視覚論 サイエンス社 針生悦子 1991 幼児における事物名解釈方略の発達 
的検討一相互排他性と文脈の利用をめぐって一教 育心理学研究, 39, 11-20.

針生悦子・大村彰道・原ひろみ 1994 未知物に関す る説明が新奇なラベルの相互排他的な解釈に及ほ す効果 発達心理学研究, 5, 41-50.

Imai, M., \& Gentner, D. 1997 A crosslinguistic study on constraints on early word meaning : Linguistic input vs. universal ontology. Cognition, 62, 169-200.

Kobayashi, H. 1997 The role of actions in making inferences about word meanings among Japanese 2-year-old children. Cognition, 63, 251-269.

Landau, B., Smith, L.B., \& Jones, S.S. 1988 The importance of shape in early lexical learning. Cognitive Development, 3, 299-321.

Markman, E.M. 1989 Categorization and naming in children : Problems of induction. Cam. bridge, MA : The MIT Press.

Nelson, K. 1988 Constraints on word learning ? Cognitive Development, 3, 221-246.

荻野美佐子 1995 語彙獲得と非言語的母子相互作用 文部省科学研究費補助金重点領域研究「認知・言 語の成立」論文集 Pp. 124-133.

Prasada, S. 1993 Learning names for solid substances : Quantifying solid entities in terms of portions. Cognitive Development, 8, 83-104.

Quine, W.V.O. 1960 Word and object. Cambridge, MA : The MIT Press.

Ross, G., Nelson, K. Wetstone, H., \& Tanouye, E. 1986 Acquisition and generalization of novel object concepts by young language learners. Journal of Child Language, 13, 67-83.

佐々木正人 1994 アフォーダンス一新しい認知の理
論 岩波書店

Snow, C.E., Perlmann, R., \& Nathan, D. 1987 Why routines are different : toward a multiple -factors model of the relation between input and language acquisition. In K.E. Nelson (Ed.) Children's language, 6, Hillsdale, $\mathrm{NJ}$ : Lawrence Erlbaum Associates.

Soja, N. 1987 Ontological constraints on 2-year -olds' induction of word meanings. Unpublished doctoral dissertation. Massachusetts Institute of Technology.

Soja, N., Carey, S., \& Spelke, E. 1991 Ontological categories guide young children's inductions of word meaning : Object terms and substance terms. Cognition, 38, 179-211.

Tomasello, M., \& Akhtar, N. 1995 Two-year -olds use pragmatic cues to differentiate reference to objects and actions. Cognitive Develop. ment, 10, 201-224.

内田伸子・今井むつみ 1996 幼児期における助数詞 の獲得過程一生物カテゴリーの形成と助数詞付与 ルールの獲得一 教育心理学研究, 44, 126-135.

梅本克夫 1951 日本語無意味音節の連想価 心理学 研究, 21, 23-28.

梅本克夫・森川弥寿雄 - 伊吹昌夫 1955 清音 2 字音 節の無連想価及び有意味度 心理学研究, 26, 148 -155 .

\section{謝 辞}

本研究に暖かいご協力を頂きました，大船ルーテル 保育園 (横浜市) とやまゆり保育園 (横浜市) の先生方と 園児の皆さんに，心より感謝致します。

(1997.6.2 受稿, 10.29 受理) 


\section{Relationship between Adults' Actions and Young Children's Inferences about Word Meanings}

Harumi Kobayashi (Kyoritsu Women's University) Japanese Journal of Educational Psychology, 1998, 46, 1-10

This study examined whether 4-year-olds and 6-year-olds attend to the relevant properties (shape or material) of solid objects in making inferences when adults demonstrate appropriate actions. In an experiment, the experimenter presented thirty-six Japanese 4-year-olds and thirty-three Japanese 6-year-olds a nonsense label with an unfamiliar standard solid object and performed an action on the object that emphasized the shape (e.g., rolling) or the material (e.g., squeezing) of these standards. The experimenter then asked these children, given the same label, to choose an object that matched the standard in shape or in material, and the reasons for their choices. The results showed that the children of both age groups used action information to make inferences about the nonsense labels. Six-year-olds were found to be more adept than 4-year-olds in attention to action-relevant object properties. The importance of adults' input and the role of actions in the acquisition of word meanings were discussed.

Key words : acquisition of word meanings, making inferences, solid objects, actions, adults' input. 